\title{
Frequentist and Bayesian inference for gas exchanges of drip-irrigated bell pepper ${ }^{1}$
}

\author{
Fernando André Silva Santos², Roberto Rezende ${ }^{3}$, \\ Gustavo Soares Wenneck ${ }^{3}$, Danilo César Santi ${ }^{3}$, Reni Saath ${ }^{3}$
}

\section{ABSTRACT}

The water deficit or excess may cause undesirable changes in yield and physiological aspects of irrigated crops. Considering the analysis of experimental data, the use of classical statistical methods may not be sufficient to detect morphological and physiological effects resulting from the conditions employed, being interesting the use of new procedures, such as the Bayesian inference. This study aimed to evaluate the gas exchanges in the bell pepper crop under irrigation depths and different irrigation times, in a protected environment, by applying the parametric and Bayesian methods. The experiment was conducted in a completely randomized design, arranged in a $5 \times 2$ factorial scheme, with five irrigation depths $(60,80,100$, 120 and $140 \%$ of the crop evapotranspiration) and two irrigation times ( 8 a.m. and 2 p.m.), with five replications. The stomatal conductance, transpiration rate, photosynthetic rate, intrinsic water-use efficiency, ratio between the photosynthetic rate and the transpiration rate, and total dry matter were evaluated. The gas exchanges were affected by water replacement depths, with little interference from the irrigation times. The linear regression models, according to the irrigation depths, for transpiration rate, stomatal conductance and total dry matter were significant for both the statistical methods, suggesting that the results are similar and even coincident, especially when a priori information are not provided in the Bayesian analysis. Differences in the photosynthetic rate were observed only with the Bayesian method, adjusting linear models according to the irrigation depths, in both the irrigation times.

KEYWORDS: Capsicum annum L., protected cultivation, micro irrigation.

\section{INTRODUCTION}

Bell pepper (Capsicum annum L.) needs a regular water supply in quantity and frequency to obtain a high yield. In cultivation under protected

\section{RESUMO}

Inferência frequentista e bayesiana para trocas gasosas de pimentão irrigado por gotejamento

O déficit ou excesso de água pode provocar alterações indesejáveis na produção e aspectos fisiológicos das culturas irrigadas. Considerando-se a análise de dados experimentais, o emprego de metodologias estatísticas clássicas pode não ser suficiente para detectar efeitos morfológicos e fisiológicos resultantes das condições empregadas, sendo interessante a utilização de novos procedimentos, como a inferência bayesiana. Objetivou-se avaliar trocas gasosas na cultura do pimentão sob lâminas de água e diferentes horários de irrigação, em ambiente protegido, aplicando-se as metodologias paramétrica e bayesiana. $\mathrm{O}$ experimento foi conduzido em delineamento inteiramente casualizado, em esquema fatorial $5 \times 2$, sendo cinco lâminas (60, 80, 100, 120 e 140 \% da evapotranspiração da cultura) e dois horários de irrigação ( 08 h e 14 h), com cinco repetições. Foram analisadas a condutância estomática, taxa transpiratória e fotossintética, eficiência intrínseca na utilização de água, razão entre a taxa fotossintética e a taxa transpiratória, e massa seca total. As trocas gasosas foram afetadas pelas lâminas de reposição de água, com pouca interferência dos horários de irrigação. Os modelos de regressão linear, em função das lâminas de água, para taxa transpiratória, condutância estomática e massa seca total foram significativos para ambas as metodologias estatísticas, sugerindo que os resultados são semelhantes e até coincidentes, principalmente quando não são fornecidas informações a priori na análise bayesiana. Diferenças para a taxa fotossintética foram obtidas apenas com o método bayesiano, ajustando-se modelos lineares em função das lâminas de água, em ambos os horários de irrigação.

PALAVRAS-CHAVE: Capsicum annum L., cultivo protegido, microirrigação.

environment conditions, the water supply occurs by irrigation, allowing the water control according to the crop demand at each development stage (Carvalho et al. 2011, Aladenola \& Madramootoo 2014, Lorenzoni et al. 2016, Silva et al. 2018a).

\footnotetext{
${ }^{1}$ Received: Oct. 30, 2020. Accepted: Mar. 18, 2021. Published: June 01, 2021. DOI: 10.1590/1983-40632021v5166435.

${ }^{2}$ Universidade do Estado de Mato Grosso, Departamento de Agronomia, Cáceres, MT, Brasil.

Email/ORCID: fernan.agr@hotmail.com/0000-0003-2220-1914.

${ }^{3}$ Universidade Estadual de Maringá, Maringá, PR, Brasil.

E-mail/ORCID: rrezende@uem.br/0000-0002-6213-1845; gustavowenneck@gmail.com/0000-0002-4151-2358; danilosantiagro@gmail.com/0000-0003-2626-5667; rsaath@uem.br/0000-0002-6610-2873.
} 
Water availability affects the crop physiology and yield. There is less aeration in the root zone and leaching of nutrients in conditions of excess of water availability. In contrast, in a deficit condition, there is a reduction in the plant growth and physiological metabolism (Silva et al. 2015). The evaluation of physiological variables, such as gas exchange, depending on the water availability, is relevant, considering that studies related to bell pepper explore the relationship between nutrition and gas exchange (Lorenzoni et al. 2018). However, information relating gas exchange and irrigation depths, for bell pepper cultivated in a protected environment, are limited. This relation deserves even a greater emphasis, when considering that gas exchanges encompass important physiological processes such as transpiration, stomatal opening and closure, and photosynthetic rate.

Generally, the classical statistical analysis involving the application of parametric procedures is sufficient to indicate differences between experimental treatments; however, some response variables may not be significant considering such analysis, being possible to opt for the application of new statistical methods that allow a better inference about the variables analyzed, such as the Bayesian one (Rossi \& Santos 2014).

The Bayesian approach has been frequently applied in several agronomic studies (Teodoro et al. 2015, Silva et al. 2018b, Blind et al. 2020), demonstrating more sensitivity to indicate differences between treatments, when compared to other parametric and non-parametric statistical methods (Rossi \& Gasparini 2012). The Bayesian statistics has many advantages, including application in several areas, from the simple comparison of averages to the adjustment of breeding models, with lower restrictions on frequent assumptions (Rossi 2011, Rossi et al. 2016).

Considering that physiological changes, mainly related to photosynthesis, have a direct effect on the development and yield of bell peppers (Lorenzoni et al. 2018), and that differences between management conditions may not be detected by classical data analysis methods, the adoption of alternative approaches is justified, aiming at obtaining results that subsidize an increase in the productive efficiency of the crop. Thus, this study aimed to evaluate the gas exchange in the bell pepper crop under irrigation depths and times, in a protected environment, by applying the parametric and Bayesian methods.

\section{MATERIAL AND METHODS}

The experiment was conducted in a protected environment, at the Universidade Estadual de Maringá $\left(23^{\circ} 25^{\prime} \mathrm{S}, 51^{\circ} 57^{\prime} \mathrm{W}\right.$ and $542 \mathrm{~m}$ of altitude), in Maringá, Paraná state, Brazil, from May 13 to September 10, 2015. The climate is classified as Cfa, according to the Köppen classification, with average annual precipitation of $1,500 \mathrm{~mm}$, temperature of 21.1-22 ${ }^{\circ} \mathrm{C}$, evapotranspiration of $1,000-1,100 \mathrm{~mm}$ and solar radiation of 14.5-15 $\mathrm{MJ} \mathrm{m}^{-2}$ day $^{-1}$ (Nitsche et al. 2019). The temperature and relative air humidity data (Figure 1) were collected by a meteorological station installed inside the protected environment.

The treatments were conducted in a completely randomized design, arranged in a $5 \times 2$ factorial scheme, with five replications. Five irrigation depths $(60,80,100,120$ and $140 \%$ of the crop evapotranspiration) and two irrigation times (8 a.m. and 2 p.m.) were evaluated. The experiment was carried out in a greenhouse covered with low-density polyethylene film $(150 \mu \mathrm{m})$ and a white anti aphid screen (40 mesh) on the sides.

The soil was classified as Nitossolo Vermelho Distroférrico (Santos et al. 2018), corresponding to a Ultisol (USA 2010), consisting of $75.60 \%$ of clay, with bulk density of $1.01 \mathrm{t} \mathrm{m}^{-3}$, and presenting, as chemical parameters: $\mathrm{pH}\left(\mathrm{CaCl}_{2}\right): 6.40$; organic matter: $15.55 \mathrm{~g} \mathrm{dm}^{-3}$; phosphorus: $46.77 \mathrm{mg} \mathrm{dm}^{-3}$; potassium: $0.30 \mathrm{cmol}_{\mathrm{c}} \mathrm{dm}^{-3}$; calcium: $11.99 \mathrm{cmol}_{\mathrm{c}} \mathrm{dm}^{-3}$; magnesium: $2.50 \mathrm{cmol}_{\mathrm{c}} \mathrm{dm}^{-3}$; aluminum: $0.00 \mathrm{cmol}_{\mathrm{c}} \mathrm{dm}^{-3}$; CEC (pH 7.0): $17.34 \mathrm{cmol}_{\mathrm{c}} \mathrm{dm}^{-3}$; base saturation: $85.35 \%$.

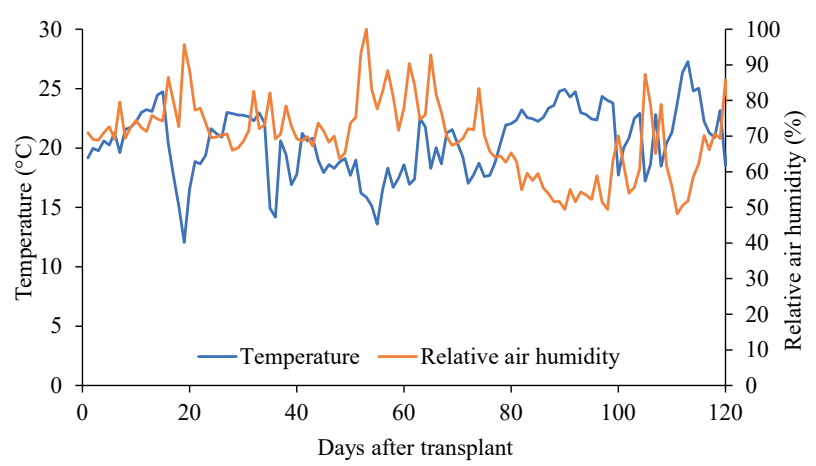

Figure 1. Temperature and relative air humidity inside the protected environment, during the bell pepper cultivation. 
In the preparation of the seedbeds, $0.5 \mathrm{~kg} \mathrm{~m}^{-2}$ of tanned cattle manure and limestone was added to increase the base saturation to $80 \%$. At 15 days before transplanting the seedlings, $40 \mathrm{~kg} \mathrm{ha}^{-1}$ of $\mathrm{N}$ in the form of ammonium sulfate and $120 \mathrm{~kg} \mathrm{ha}^{-1}$ of $\mathrm{P}_{2} \mathrm{O}_{5}$ in the form of simple superphosphate (Pauletti \& Motta 2017) were applied.

The sowing of the Magali $\mathrm{R}$ hybrid was performed in plastic trays of 50 cells, filled with a commercial substrate based on hummus and pine. The transplant occurred using the spacing of $0.5 \mathrm{~m}$ between plants and $1.0 \mathrm{~m}$ between seedbeds, with seedlings presenting from three to four leaves (Martinez et al. 2016) and arrangement of experimental units in a protected environment.

Irrigation was performed by a drip micro irrigation system, with a polyethylene lateral line of $16 \mathrm{~mm}$ in diameter containing twelve selfcompensating drippers spaced at $0.25 \mathrm{~m}$ and nominal flow of $8 \mathrm{~L} \mathrm{~h}^{-1}$, operating at a pressure of $15 \mathrm{mH}_{2} \mathrm{O}$, with a statistical uniformity coefficient of $95.21 \%$, which is above the acceptable minimum (Frizzone et al. 2012).

The irrigation was managed considering the crop evapotranspiration (ETc), determined using two constant groundwater lysimeters, with automatic and uninterrupted replacement of evapotranspiration water. Four plants were transplanted in each lysimeter, following the spacing of the other plants in the beds. The ETc readings and water reservoir reposition were performed daily in the morning (7 a.m.) (Vellame et al. 2012), with a reading interval of 24 hours, to agree with the real evapotranspiration values. Although the periods of water replacement have an interval of 6 hours, the difference in the amount of water is supplied in the subsequent irrigation. The adoption of readings in a period of the day was adopted to reduce the impact of the water column in the replacement tank and errors associated with readings, which could systematically interfere in the final results.

The gas exchanges were determined with an infrared gas analyzer - IRGA, model LCPro ${ }^{+}$Portable Photosynthesis System ${ }^{\mathrm{TM}}$ (ADC BioScientific Limted, UK), using room temperature and light source with irradiation of $600 \mu \mathrm{mol} \mathrm{m} \mathrm{m}^{-2} \mathrm{~s}^{-1}$, and readings were made between 8:30 a.m. and 9:30 a.m., using the third leaf from the plant apex, during the fruiting phase (Lorenzoni et al. 2018). The stomatal conductance, transpiration rate, photosynthetic rate and intrinsic water-use efficiency, calculated from the ratio between the photosynthetic rate and the transpiration rate, were analyzed.

At the end of the experiment, the plants were cut $2 \mathrm{~cm}$ above the soil surface to determine the total dry matter, in a greenhouse with forced air circulation, with temperature of $65^{\circ} \mathrm{C}$, until reaching a constant weight (Souza et al. 2002).

Considering the factorial scheme adopted, the choice was to focus on the possible interactions between the factors studied, analyzing the consequences regardless of the significance of the interaction, since, in the unfolding, significance can be detected, what provides important results, with a detailed procedure described by Perecin \& Cargnelutti Filho (2008).

In the frequentist approach, the results were submitted to analysis of variance, and the F test was conclusive in the comparison of irrigation times. Regression analysis was used for the irrigation depths, testing models up to the quadratic level. The analyses were performed at a maximum probability level of $5 \%$, using the ExpDes package of the $\mathrm{R}$ program (R Core Team 2017).

In the Bayesian method, the hour factor was analyzed using contrasts between the a posteriori distribution of the means. To the irrigation depths, the a posteriori distribution of coefficients of the regression models up to the quadratic level was tested. Non-informative priors were considered for the parameters in both the Bayesian analyses. The significance of the coefficients and contrasts was obtained considering the probability level of $5 \%$, observing whether the zero value was not contained in the credible intervals (CrI $95 \%$ ).

The a posteriori marginal distributions for all the parameters were obtained by the BRugs package of the R software (R Core Team 2017). For this, 500,000 values were generated in a Markov Chain Monte Carlo process, considering a sampling disposal time of 10,000 initial values, making up the final sample containing 50,000 values generated after being taken in size ten jumps. The convergence of the chains was verified by the coda package of the R software at the Heidelberger \& Welch (1983) criterion.

\section{RESULTS AND DISCUSSION}

There was no significant effect between the water depths and irrigation times $(\mathrm{p}>0.05)$ for the gas exchange and biomass accumulation evaluated 
in the bell pepper plants. There was a significant isolated effect of irrigation depths on transpiration rate, stomatal conductance and total dry matter $(\mathrm{p}<0.01)$. The photosynthetic rate and intrinsic water-use efficiency were not affected by any of the factors evaluated. By the frequentist approach, in the unfolding of the irrigation times within each irrigation depth, no differences were found between schedules $(p>0.05)$ for the variables analyzed (Table 1).

The application of the Bayesian analysis, in the comparison between times in each irrigation depth, was not more advantageous, when compared to the frequentist estimate, concerning the gas exchange and total dry matter. Despite the little distinction between the mean values obtained by the two analyses, in the Bayesian methodology the a posteriori estimate of the means differed significantly [the zero value is not contained $(\not \subset)$ in the credible intervals $(\mathrm{CI})]$ $(0 \not \subset \mathrm{CI} ; \mathrm{p}<0.05)$ between times for the intrinsic water-use efficiency, in the irrigation depth of $80 \%$ of the ETc, with a greater efficiency when irrigation was performed in the morning (Table 2).

Given the absence of differences between the irrigation times, the water application performed in the morning period allowed the plant to have an adequate water availability throughout the day. The irrigation depths applied in the afternoon coincided with a period of greater evapotranspiration, increasing the relative air humidity inside the protected environment (Vellame et al.2012), favoring the occurrence and dissemination of pathogens, thus establishing an unfavorable condition in the phytosanitary management (Weintraub et al. 2017).

According to the frequentist estimate, Table 3 presents regression analyses in response to the water depths applied for the two irrigation times. For the variables transpiration rate, stomatal conductance and total dry matter, increasing linear adjustments were obtained, since there was an increase in the irrigation depths applied for the two irrigation times. The photosynthetic rate and intrinsic water-use efficiency were not affected by the irrigation depths at both times.

Based on the Bayesian method, it was observed that the regression of the irrigation depths applied in the two irrigation times was significant $(0 \not \subset \mathrm{CI}$; $\mathrm{p}<0.05)$, since the zero value is not contained in the credible intervals in a posteriori estimates of the coefficients (Table 4). For the transpiration rate, stomatal conductance and total dry matter, increasing linear adjustments were obtained, since there was an increase in the irrigation depths applied in the two irrigation times, as observed in the frequentist method.

The estimates of the regression coefficients by the Bayesian method were significant $(0 \not \subset \mathrm{CI}$; $\mathrm{p}<0.05$ ) for photosynthetic rate in the two irrigation times. The intrinsic water-use efficiency in the morning hours was not verified when the frequentist

Table 1. Summary of the results of the frequentist method for photosynthetic rate, transpiration rate, stomatal conductance, intrinsic water-use efficiency and total dry matter of the Magali $\mathrm{R}$ bell pepper hybrid, in the unfolding of irrigation times in each irrigation depth applied, in a protected environment.

\begin{tabular}{|c|c|c|c|c|c|c|}
\hline \multirow{2}{*}{ Variable } & \multirow{2}{*}{ Irrigation time } & \multicolumn{5}{|c|}{ Irrigation depth $(\mathrm{mm})$} \\
\hline & & 60 & 80 & 100 & 120 & 140 \\
\hline \multirow{3}{*}{$\begin{array}{l}\text { Photosynthetic rate } \\
\left(\mu \mathrm{mol} \mathrm{CO}_{2} \mathrm{~m}^{-2} \mathrm{~s}^{-1}\right)\end{array}$} & Morning & 8.970 & 10.010 & 9.440 & 10.410 & 11.230 \\
\hline & Afternoon & 8.670 & 8.500 & 9.880 & 9.920 & 10.310 \\
\hline & p-value ${ }^{1}$ & 0.845 & 0.327 & 0.775 & 0.751 & 0.550 \\
\hline \multirow{3}{*}{$\begin{array}{l}\text { Transpiration rate } \\
\left(\mathrm{mmol} \mathrm{m}^{-2} \mathrm{~s}^{-1}\right)\end{array}$} & Morning & 1.650 & 1.860 & 1.930 & 2.200 & 2.130 \\
\hline & Afternoon & 1.710 & 1.510 & 1.910 & 1.890 & 2.220 \\
\hline & p-value ${ }^{1}$ & 0.769 & 0.084 & 0.887 & 0.122 & 0.656 \\
\hline \multirow{3}{*}{$\begin{array}{l}\text { Stomatal conductance } \\
\qquad\left(\mathrm{mol} \mathrm{m}^{-2} \mathrm{~s}^{-1}\right)\end{array}$} & Morning & 0.210 & 0.210 & 0.230 & 0.310 & 0.320 \\
\hline & Afternoon & 0.180 & 0.180 & 0.280 & 0.250 & 0.290 \\
\hline & p-value ${ }^{1}$ & 0.358 & 0.276 & 0.230 & 0.133 & 0.389 \\
\hline \multirow{3}{*}{$\begin{array}{c}\text { Intrinsic water-use efficiency } \\
{\left[\left(\mu \mathrm{mol} \mathrm{CO} \mathrm{CO}^{-2} \mathrm{~s}^{-1}\right) /\left(\mathrm{mmol} \mathrm{m}^{-2} \mathrm{~s}^{-1}\right)\right]}\end{array}$} & Morning & 5.460 & 5.640 & 4.880 & 4.750 & 5.420 \\
\hline & Afternoon & 5.160 & 5.490 & 5.140 & 5.190 & 4.670 \\
\hline & p-value ${ }^{1}$ & 0.728 & 0.865 & 0.768 & 0.620 & 0.399 \\
\hline \multirow{3}{*}{$\begin{array}{l}\text { Total dry matter } \\
\quad\left(\mathrm{g} \text { plant }^{-1}\right)\end{array}$} & Morning & 36.930 & 38.560 & 44.740 & 39.770 & 66.610 \\
\hline & Afternoon & 41.820 & 44.000 & 45.930 & 50.980 & 53.770 \\
\hline & p-value ${ }^{1}$ & 0.553 & 0.510 & 0.885 & 0.179 & 0.124 \\
\hline
\end{tabular}

${ }^{1}$ Probability for the F-test. 
Table 2. Summary of the results of the Bayesian method for photosynthetic rate, transpiration rate, stomatal conductance, intrinsic water-use efficiency and total dry matter of the Magali $\mathrm{R}$ bell pepper hybrid, in the unfolding of irrigation times in each irrigation depth applied, in a protected environment.

\begin{tabular}{|c|c|c|c|c|c|c|}
\hline \multirow{2}{*}{ Variable } & \multirow{2}{*}{ Irrigation time } & \multicolumn{5}{|c|}{ Irrigation depth $(\mathrm{mm})$} \\
\hline & & 60 & 80 & 100 & 120 & 140 \\
\hline \multirow{3}{*}{$\begin{array}{l}\text { Photosynthetic rate } \\
\left(\mu \mathrm{mol} \mathrm{CO} \mathrm{m}^{-2} \mathrm{~s}^{-1}\right)\end{array}$} & Morning & $7.39(0.91)^{(1)}$ & $9.41(1.33)$ & $9.88(1.02)$ & $11.80(1.34)$ & $11.23(0.54)$ \\
\hline & Afternoon & $7.01(1.04)$ & $9.10(1.32)$ & $9.44(1.01)$ & $11.10(1.15)$ & $10.69(0.61)$ \\
\hline & CI & $\mathrm{ns}$ & ns & ns & ns & ns \\
\hline \multirow{3}{*}{ 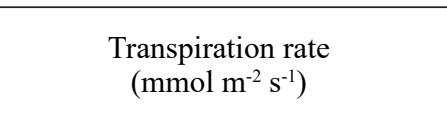 } & Morning & $1.65(0.15)$ & $1.86(0.14)$ & $1.93(0.12)$ & $2.20(0.19)$ & $2.13(0.17)$ \\
\hline & Afternoon & $1.71(0.15)$ & $1.51(0.14)$ & $1.91(0.13)$ & $1.89(0.19)$ & $2.22(0.17)$ \\
\hline & $\mathrm{CI}$ & ns & ns & ns & ns & ns \\
\hline \multirow{3}{*}{$\begin{array}{l}\text { Stomatal conductance } \\
\left(\mathrm{mol} \mathrm{m}^{-2} \mathrm{~s}^{-1}\right)\end{array}$} & Morning & $0.21(0.02)$ & $0.21(0.01)$ & $0.23(0.03)$ & $0.31(0.03)$ & $0.32(0.03)$ \\
\hline & Afternoon & $0.18(0.02)$ & $0.18(0.01)$ & $0.28(0.03)$ & $0.25(0.03)$ & $0.29(0.03)$ \\
\hline & $\mathrm{CI}$ & ns & ns & ns & ns & ns \\
\hline \multirow{3}{*}{$\begin{array}{c}\text { Intrinsic water-use efficiency } \\
{\left[\left(\mu \mathrm{mol} \mathrm{CO} \mathrm{m}^{-2} \mathrm{~s}^{-1}\right) /\left(\mathrm{mmol} \mathrm{m}^{-2} \mathrm{~s}^{-1}\right)\right]}\end{array}$} & Morning & $4.49(0.28)$ & $5.95(0.57)$ & $4.88(0.37)$ & $5.19(0.67)$ & $4.58(0.61)$ \\
\hline & Afternoon & $4.45(0.28)$ & $4.16(0.65)$ & $5.14(0.37)$ & $5.19(0.52)$ & $4.89(0.52)$ \\
\hline & $\mathrm{CI}$ & ns & $*$ & ns & ns & ns \\
\hline \multirow{3}{*}{$\begin{array}{l}\text { Total dry matter } \\
\quad\left(\mathrm{g} \text { plant }{ }^{-1}\right)\end{array}$} & Morning & $33.28(5.25)$ & $38.58(7.09)$ & $44.76(6.33)$ & $39.79(4.57)$ & $58.44(7.63)$ \\
\hline & Afternoon & $39.32(5.21)$ & $44.00(7.11)$ & $45.93(6.35)$ & $50.98(4.59)$ & $53.70(6.90)$ \\
\hline & CI & ns & ns & ns & ns & ns \\
\hline
\end{tabular}

Table 3. Frequentist estimates of regression coefficients for photosynthetic rate, transpiration rate, stomatal conductance, intrinsic water-use efficiency and total dry matter of the Magali R bell pepper hybrid, in the unfolding of irrigation depths applied in each irrigation time, in a protected environment.

\begin{tabular}{|c|c|c|c|c|c|}
\hline Variable & Irrigation time & Coefficients & Estimate & Standard error & p-value ${ }^{1}$ \\
\hline \multirow{4}{*}{$\begin{array}{l}\text { Photosynthetic rate } \\
\left(\mu \mathrm{mol} \mathrm{CO}_{2} \mathrm{~m}^{-2} \mathrm{~s}^{-1}\right)\end{array}$} & \multirow{2}{*}{ Morning } & $\beta 0$ & 7.556 & 1.768 & $0.000 * *$ \\
\hline & & $\beta 1$ & 0.025 & 0.017 & $0.156^{\mathrm{ns}}$ \\
\hline & \multirow{2}{*}{ Afternoon } & $\beta 0$ & 7.109 & 1.768 & $0.000 * *$ \\
\hline & & $\beta 1$ & 0.024 & 0.017 & $0.175^{\text {ns }}$ \\
\hline \multirow{4}{*}{$\begin{array}{l}\text { Transpiration rate } \\
\left(\mathrm{mmol} \mathrm{m} \mathrm{m}^{-2} \mathrm{~s}^{-1}\right)\end{array}$} & \multirow{2}{*}{ Morning } & $\beta 0$ & 1.311 & 0.228 & $0.000 * *$ \\
\hline & & $\beta 1$ & 0.006 & 0.002 & $0.005 * *$ \\
\hline & \multirow{2}{*}{ Afternoon } & $\beta 0$ & 1.154 & 0.228 & $0.000 * *$ \\
\hline & & $\beta 1$ & 0.007 & 0.002 & $0.003 * *$ \\
\hline \multirow{4}{*}{$\begin{array}{l}\text { Stomatal conductance } \\
\qquad\left(\mathrm{mol} \mathrm{m}^{-2} \mathrm{~s}^{-1}\right)\end{array}$} & \multirow{2}{*}{ Morning } & $\beta 0$ & 0.109 & 0.040 & $0.010^{*}$ \\
\hline & & $\beta 1$ & 0.002 & 0.000 & $0.000 * *$ \\
\hline & \multirow{2}{*}{ Afternoon } & $\beta 0$ & 0.092 & 0.040 & $0.027 *$ \\
\hline & & $\beta 1$ & 0.001 & 0.000 & $0.001 * *$ \\
\hline \multirow{4}{*}{$\begin{array}{c}\text { Intrinsic water-use efficiency } \\
{\left[\left(\mu \mathrm{mol} \mathrm{CO} \mathrm{C}^{-2} \mathrm{~s}^{-1}\right) /\left(\mathrm{mmol} \mathrm{m}^{-2} \mathrm{~s}^{-1}\right)\right]}\end{array}$} & \multirow{2}{*}{ Morning } & $\beta 0$ & 5.727 & 1.011 & $0.000 * *$ \\
\hline & & $\beta 1$ & -0.005 & 0.010 & $0.616^{\mathrm{ns}}$ \\
\hline & \multirow{2}{*}{ Afternoon } & $\beta 0$ & 5.773 & 1.011 & $0.000 * *$ \\
\hline & & $\beta 1$ & -0.006 & 0.010 & $0.515^{\mathrm{ns}}$ \\
\hline \multirow{4}{*}{$\begin{array}{l}\text { Total dry matter } \\
\quad\left(\mathrm{g}_{\text {plant }}{ }^{-1}\right)\end{array}$} & \multirow{2}{*}{ Morning } & $\beta 0$ & 20.904 & 9.507 & $0.034 *$ \\
\hline & & $\beta 1$ & 0.254 & 0.091 & $0.008 * *$ \\
\hline & \multirow{2}{*}{ Afternoon } & $\beta 0$ & 25.999 & 9.507 & $0.009 * *$ \\
\hline & & $\beta 1$ & 0.203 & 0.092 & $0.032 *$ \\
\hline
\end{tabular}

${ }^{1}$ Probability for the student t-test; $\beta 0$ : constant of the model; $\beta 1$ : linear coefficient of the model. $*$ and $* *$ : significant at $5 \%$ and $1 \%$ of probability, respectively; ${ }^{\text {ns }}$ nonsignificant at $5 \%$ of probability.

method was applied. For these variables, increasing linear models were also adjusted according to the water depths (Table 4).
For the present experimental conditions, it was found that the methods were a little divergent, both in the differences established between the irrigation 
Table 4. A posteriori Bayesian estimates of regression coefficients for photosynthetic rate, transpiration rate, stomatal conductance, intrinsic water-use efficiency and total dry matter of the Magali R bell pepper hybrid, in the unfolding of irrigation depths applied in each irrigation time, in a protected environment.

\begin{tabular}{|c|c|c|c|c|}
\hline Variable & Irrigation time & Coefficients & Average (SD) & CI \\
\hline \multirow{4}{*}{$\begin{array}{l}\text { Photosynthetic rate } \\
\left(\mu \mathrm{mol} \mathrm{CO}_{2} \mathrm{~m}^{-2} \mathrm{~s}^{-1}\right)\end{array}$} & \multirow{2}{*}{ Morning } & $\beta 0$ & $4.606(1.204)$ & $(2.214 ; 6.989)^{*}$ \\
\hline & & $\beta 1$ & $0.049(0.011)$ & $(0.027 ; 0.072)^{*}$ \\
\hline & \multirow{2}{*}{ Afternoon } & $\beta 0$ & $5.429(1.764)$ & $(1.946 ; 8.943)^{*}$ \\
\hline & & $\beta 1$ & $0.043(0.017)$ & $(0.009 ; 0.077)^{*}$ \\
\hline \multirow{4}{*}{$\begin{array}{l}\text { Transpiration rate } \\
\left(\mathrm{mmol} \mathrm{m} \mathrm{m}^{-2} \mathrm{~s}^{-1}\right)\end{array}$} & \multirow{2}{*}{ Morning } & $\beta 0$ & $1.314(0.264)$ & $(0.787 ; 1.830)^{*}$ \\
\hline & & $\beta 1$ & $0.006(0.002)$ & $(0.001 ; 0.011)^{*}$ \\
\hline & \multirow{2}{*}{ Afternoon } & $\beta 0$ & $1.156(0.209)$ & $(0.007 ; 0.002)^{*}$ \\
\hline & & $\beta 1$ & $0.007(0.002)$ & $(0.003 ; 0.011)^{*}$ \\
\hline \multirow{4}{*}{$\begin{array}{l}\text { Stomatal conductance } \\
\qquad\left(\mathrm{mol} \mathrm{m}^{-2} \mathrm{~s}^{-1}\right)\end{array}$} & \multirow{2}{*}{ Morning } & $\beta 0$ & $0.109(0.041)$ & $(0.027 ; 0.189)^{*}$ \\
\hline & & $\beta 1$ & $0.001(0.0004)$ & $(0.0007 ; 0.0023)^{*}$ \\
\hline & \multirow{2}{*}{ Afternoon } & $\beta 0$ & $0.092(0.045)$ & $(0.003 ; 0.180)^{*}$ \\
\hline & & $\beta 1$ & $0.0015(0.0004)$ & $(0.0006 ; 0.0023)^{*}$ \\
\hline \multirow{4}{*}{$\begin{array}{c}\text { Intrinsic water-use efficiency } \\
{\left[\left(\mu \mathrm{mol} \mathrm{CO} \mathrm{C}^{-2} \mathrm{~s}^{-1}\right) /\left(\mathrm{mmol} \mathrm{m}^{-2} \mathrm{~s}^{-1}\right)\right]}\end{array}$} & \multirow{2}{*}{ Morning } & $\beta 0$ & $3.880(0.308)$ & $(-0.629 ; 0.547)^{\mathrm{ns}}$ \\
\hline & & $\beta 1$ & $0.008(0.004)$ & $(0.0003 ; 0.0169)^{*}$ \\
\hline & \multirow{2}{*}{ Afternoon } & $\beta 0$ & $4.545(0.908)$ & $(2.738 ; 6.344)^{*}$ \\
\hline & & $\beta 1$ & $0.006(0.009)$ & $(-0.011 ; 0.023)^{\mathrm{ns}}$ \\
\hline \multirow{4}{*}{$\begin{array}{l}\text { Total dry matter } \\
\quad\left(\mathrm{g}_{\text {plant }}{ }^{-1}\right)\end{array}$} & \multirow{2}{*}{ Morning } & $\beta 0$ & $24.860(8.233)$ & $(8.491 ; 41.110)^{*}$ \\
\hline & & $\beta 1$ & $0.189(0.079)$ & $(0.033 ; 0.346)^{*}$ \\
\hline & \multirow{2}{*}{ Afternoon } & $\beta 0$ & $22.570(10.420)$ & $(2.059 ; 43.240)^{*}$ \\
\hline & & $\beta 1$ & $0.232(0.099)$ & $(0.034 ; 0.426)^{*}$ \\
\hline
\end{tabular}

SD: standard deviation; CI: credible interval of $95 \%$; $\beta 0$ : constant of the model; $\beta 1$ : linear coefficient of the model. * significant at $5 \%$ of probability; ${ }^{\text {ns }}$ non-significant at $5 \%$ of probability.

times and for the regression models, according to the applied irrigation depths. This can be confirmed by the estimates obtained for the variables analyzed with the frequentist method (Tables 1 and 3), which were similar (total dry matter), and some identical (transpiration) to those obtained with the Bayesian method (Tables 2 and 4).

This occurrence can be explained by using non-informative priors in the Bayesian analysis, for the variables analyzed, analogous to that observed in other studies involving the comparison of statistical frequentist and Bayesian methods (Rossi \& Gasparini 2012).

In researches involving irrigation, quadratic regression adjustments are commonly obtained, attributing a maximum yield according to the irrigation use without proportional increases as there is an increase in the irrigation levels. Albuquerque et al. (2011) evaluated the Maximos F1 bell pepper hybrid and found a poor quadratic adjustment for the variable yield, according to five irrigation levels (80, $90,100,110$ and $120 \%$ of the ETc).

This tendency could be maintained in evaluating physiological variables; however, with the application of $140 \%$ of the ETc in the present study, it was impossible to obtain an irrigation depth that allows non-proportional gas exchanges and dry matter accumulation in the bell peppers.

In the context of the relation between bell pepper water depths and gas exchange, few studies are available in the literature, being more frequent researches that evaluate gas exchange and other physiological variables (chlorophyll fluorescence and leaf pigments) as a function of salinity of irrigation water (Melo et al. 2017) or irrigation (Guang-Cheng et al. 2010, Zhu et al. 2012).

The results of gas exchange in other irrigated solanaceous with different replacement levels are different from those obtained in this experiment, such as that observed for the eggplant crop (Silva et al. 2015), in which the application of five irrigation depths $(33,66,100,133$ and $166 \%$ of the ETc) provided quadratic adjustments for variables such as photosynthetic rate, transpiration and stomatal conductance, and increasing and decreasing linear adjustments for chlorophyll fluorescence and leaf temperature, respectively. During the experimental period, the ETc was measured daily in two lysimeters, 
indicating a rigor in the data collection, thus reducing possible errors in determining the crop evapotranspiration.

The use of constant groundwater lysimeters is adopted to determine the water needs of vegetables, mainly for a protected environment (Lozano et al. 2017). In the constant groundwater lysimeters, the presence of the groundwater level does not represent the conditions of the experimental plot and alters the crop growth, being higher within the lysimeters, what results in a greater exposure to radiation and wind effects, culminating in overestimation of evapotranspiration values by up to 10 or $20 \%$ (Materán et al. 2009).

Opposite to what is described, underestimating the ETc during the experiment could be reflected in the linear trends observed in the bell pepper plants response variables, considering the irrigation depths corresponding to the evapotranspiration fractionation.

When considering factors such as soil cover, available water and crop, they can be determinant to obtain linear adjustments in isolation or jointly. Regarding the water and soil cover, it is considered that evapotranspiration occurs at a high rate in the absence of water limitation, being conditioned by available energy and plant physiological aspects, such as stomatal opening (Carvalho et al. 2019). Under the methodological conditions adopted, with constant groundwater lysimeters, the evapotranspiration of the crop was obtained with no data for water evaporation from the soil or plant transpiration in isolation. Considering that the lysimeters used to determine the ETc in the protected environment presented a surface free of dead vegetation cover, it is permissible that even in an experimental condition favorable to high evapotranspiration, the evaporation process did not contribute to overestimating the ETc values. The transpiration of the bell pepper was reduced, even with the presence of the constant groundwater, which did not restrict the water flow from the soil to the plants.

The water flow maintenance can be validated indirectly by the significance obtained for the transpiration rate and stomatal conductance, since there was an increase in water availability for both the statistical analyses addressed.

Also, considering the interrelation between physiological aspects of the crop, with increased transpiration rate and stomatal conductance, there was an increase in the photosynthetic rate and possibly carbon assimilation by plants, what resulted in a higher crop growth, being represented by the total dry matter of the plants.

The significant increase in the total dry matter was due to the increase of irrigation depths following the linear trend for gas exchange being equally efficient in water use in the photosynthetic process. However, it should be highlighted that such arguments are appropriate if the estimates made with the Bayesian method are considered, and it indicated a significance for the transpiration rate, stomatal conductance, total dry matter and photosynthetic rate.

Although there are few differences in the regression adjustments with the application of the frequentist and Bayesian analyses, it is recommended that the Bayesian method be used to evaluate experiments involving gas exchange and irrigation. However, it is not always possible to obtain data that meet assumptions of the frequentist analysis (normality and homoscedasticity of variances), given the possibility of greater variation in physiological data, usually from a single measurement, being, therefore, susceptible to a greater experimental error.

It can also be contextualized that the Bayesian inference has been a more interesting alternative for experiments involving regression models, as observed for other areas of agricultural sciences (Rossi \& Santos 2014, Souza et al. 2016).

Rossi \& Gasparini (2012) state that using more representative models, regarding the study characteristics, together with an appropriate methodology is essential, reinforcing the idea that using the Bayesian method in studies with irrigation may represent an important development, considering the method robustness.

\section{CONCLUSIONS}

1. The frequentist and Bayesian methods present similar results for gas exchanges of bell peppers, being more affected by irrigation depths than by irrigation times;

2. The application of up to $140 \%$ of the crop evapotranspiration alters the transpiration rate, stomatal conductance and total dry matter of bell pepper, with the same tendency in the two irrigation times, regardless of the statistical method applied; 
3. The Bayesian method is more sensitive than the frequentist one to indicate changes in the photosynthetic rate of bell pepper according to the irrigation depths, and can be applied to other variables related to the crop development, in order to allow a detailed analysis of the impact of management conditions on productive efficiency.

\section{REFERENCES}

ALADENOLA, O.; MADRAMOOTOO, C. Response of greenhouse-grown bell pepper (Capsicum annuиm L.) to variable irrigation. Canadian Journal of Plant Science, v. 94, n. 2, p. 303-310, 2014.

ALBUQUERQUE, F. da S.; SILVA, Ê. F. de F. e; ALBUQUERQUE FILHO, J. A. C. de; NUNES, M. F. F. N. Crescimento e rendimento de pimentão fertigado sob diferentes lâminas de irrigação e doses de potássio. Revista Brasileira de Engenharia Agrícola e Ambiental, v. 15, n. 7, p. 686-694, 2011.

BLIND, A. D.; ALMEIDA, F. V. A.; VALENTE, M. S. F.; COSTA NETO, P. Q.; LOPES, M. T. G.; SILVA FILHO, D. F. Marcadores moleculares e descritores morfo-agronômicos na avaliação da diversidade genética de bucha (Luffa cylindrica). Colloquium Agrariae, v. 16, n. 1, p. 66-76, 2020.

CARVAlHO, J. de A.; REZENDE, F. C.; AQUINO, R. F.; FREITAS, W. A. de; OLIVEIRA, E. C. Análise produtiva e econômica do pimentão-vermelho irrigado com diferentes lâminas, cultivado em ambiente protegido. Revista Brasileira de Engenharia Agrícola e Ambiental, v. 15, n. 6, p. 569-574, 2011.

CARVALHO, K. S.; VIANNA, M. S.; NASSIF, D. S. P.; COSTA, L. G.; FOLEGATTI, M. V.; MARIN, F. R. Effect of soil straw cover on evaporation, transpiration, and evapotranspiration in sugarcane cultivation. Australian Journal of Crop Science, v. 13, n. 8, p. 1362-1368, 2019.

FRIZZONE, J. A.; FREITAS, P. S. L. de; REZENDE, R.; FARIA, M. A. de. Microirrigação: gotejamento e microaspersão. Maringá: Eduem, 2012.

GUANG-CHENG, S.; NA, L.; ZHAN-YU, Z.; SHUANGEN, Y.; CHANG-REN, C. Growth, yield and water use efficiency response of greenhouse-grown hot pepper under time-space deficit irrigation. Scientia Horticulturae, v. 126, n. 2, p. 172-179, 2010.

HEIDELBERGER, P.; WELCH, P. Simulation run length control in the presence of an initial transient. Operations Research, v. 31, n. 6, p. 1109-1144, 1983.

LORENZONI, M. Z.; REZENDE, R.; SOUZA, A. H. C. de; SANTOS, F. A. S.; LOZANO, C. S.; SERON, C. de C.
Gas exchange, leaf and root dry mass in bell pepper under fertigation with nitrogen and potassium. Semina: Ciências Agrárias, v. 39, n. 2, p. 511-520, 2018.

LORENZONI, M. Z.; REZENDE, R.; SOUZA, A. H. C. de; SERON, C. de C.; HACHMANN, T. L.; FREITAS, P. S. L. de. Response of bell pepper crop fertigated with nitrogen and potassium doses in protected environment. Agrotechnology, v. 5, n. 2, e10001148, 2016.

LOZANO, C. S.; REZENDE, R.; FREITAS, P. S. L. de; HACHMANN, T. L.; SANTOS, F. A. S.; ANDREAN, A. F. B. A. Estimatation of evapotranspiration and crop coefficient of melon cultivated in protected environment. Revista Brasileira de Engenharia Agrícola e Ambiental, v. 21, n. 11, p. 758-762, 2017.

MARTINEZ, L. P. G.; TAVARES, S. A.; CARVALHO, F. I. R.; BORGES, P. R. S.; SOARES, R. G.; GONTIJO, G. M. Boas práticas agrícolas na produção de pimentão. Brasília, DF: Emater, 2016.

MATERÁN, F. J. V.; OLIVEIRA, R. A. de; SEDIYAMA, G. C.; CECON, P. R.; RUIZ, H. A.; TAGLIAFERRE, C. Minilisímetro com lençol freático constante operando com Irrigâmetro ${ }^{\circledR}$ para medida da evapotranspiração de referência. Revista UDO Agrícola, v. 9, n. 1, p. 243-258, 2009.

MELO, H. F. de; SOUZA, E. R. de; DUARTE, H. H. F.; CUNHA, J. C.; SANTOS, H. R. B. Gas exchange and photosynthetic pigments in bell pepper irrigated with saline water. Revista Brasileira de Engenharia Agrícola e Ambiental, v. 21, n. 1, p. 38-43, 2017.

NITSCHE, P. R.; CARAMORI, P. H.; RICCE, W. S.; PINTO, L. F. D. Atlas climático do estado do Paraná. Londrina: Iapar, 2019.

PAULETTI, V.; MOTTA, A. C. V. Manual de adubação e calagem para o estado do Paraná. Curitiba: SBCS/ Nepar, 2017.

PERECIN, D.; CARGNELUTTI FILHO, A. Efeitos por comparações e por experimento em interações de experimentos fatoriais. Ciência e Agrotecnologia, v. 32, n. 1, p. 68-72, 2008.

R CORE TEAM. $R$ : a language and environment for statistical computing. Vienna: The R Foundation for Statistical Computing, 2017.

ROSSI, R. M. Introdução aos métodos bayesianos na análise de dados zootécnicos com uso do WinBUGS e R. Maringá: Eduem, 2011.

ROSSI, R. M.; GASPARINI, D. C. de S. O uso de procedimentos estatísticos para comparação da produção de ovos considerando diferentes tratamentos e linhagens de codornas. Semina: Ciências Agrárias, v. 33, n. 1, p. 17-26, 2012. 
ROSSI, R. M.; MARTINS, E. N.; LOPES, P. S.; SILVA, F. F.; MARCONDES, M. I.; CAETANO, G. C.; FERREIRA JÚNIOR, H. C.; KNUPP, L. S.; FERREIRA, M. A. Inferência bayesiana da conversão alimentar em diferentes experimentos animais. Arquivo Brasileiro de Medicina Veterinária e Zootecnia, v. 68, n. 2, p. 466-474, 2016.

ROSSI, R. M.; SANTOS, L. A. dos. Modelagem bayesiana para curvas de crescimentos de codornas assumindo assimetria nos erros. Semina: Ciências Agrárias, v. 35, n. 3, p. 1637-1648, 2014.

SANTOS, H. G.; JACOMINE, P. K. T.; ANJOS, L. H. C.; OLIVEIRA, V. Á.; LUMBRERAS, J. F.; COELHO, M. R.; ALMEIDA, J. A.; ARAÚJO FILHO, J. C.; OLIVEIRA, J. B.; CUNHA, T. J. F. Sistema brasileiro de classificação de solos. 5. ed. Brasília, DF: Embrapa, 2018.

SILVA, A. J.; SANCHES, A.; ANDRADE, A. C. B.; OLIVEIRA, G. H. F.; MAURO, A. O. Di. Bayesian approach, traditional method, and mixed models for multienvironment trials of soybean. Pesquisa Agropecuária Brasileira, v. 53, n. 10, p. 1093-1100, 2018 b.

SILVA, F. G. da; DUTRA, W. F.; DUTRA, A. F.; OLIVEIRA, I. M. de; FILGUEIRAS, L. M. B.; MELO, A. S. de. Trocas gasosas e fluorescência da clorofila em plantas de berinjela sob lâminas de irrigação. Revista Brasileira de Engenharia Agrícola e Ambiental, v. 19, n. 10, p. 946-952, 2015.

SILVA, G. H. da; FERREIRA, M. G.; PEREIRA, S. B.; DELAZARI, F. T.; SILVA, D. J. H. da. Response of bell pepper crop subjected to irrigation depths calculated by different methodologies. Revista Brasileira de Engenharia Agrícola e Ambiental, v. 22, n. 1, p. 45-50, 2018 a.
SOUZA, G. B.; NOGUEIRA, A. R. A.; RASSINI, J. B. Determinação de matéria seca e umidade em solos e plantas com forno de micro-ondas doméstico. São Carlos: Embrapa, 2002.

SOUZA, O. M.; MARTINS, E. N.; ROSSI, R. M.; OLIVEIRA, C. A. L. de; AGUIAR, S. C. de; PAULA, E. J. H. de; GERON, L. J. V.; STIVANIN, T. E.; FERREIRA, E. B. Ruminal $\mathrm{pH}$ and $\mathrm{N}-\mathrm{NH}_{3}$ behavior: a bayesian approach. Semina: Ciências Agrárias, v. 37, n. 1, p. 311-320, 2016.

TEODORO, P. E.; NASCIMENTO, M.; TORRES, F. E.; BARROSO, L. M. A.; SAGRILO, E. Perspectiva bayesiana na seleção de genótipos de feijão-caupi em ensaios de valor de cultivo e uso. Pesquisa Agropecuária Brasileira, v. 50, n. 10, p. 878-885, 2015.

USA. Soil Survey Staff. Keys to soil taxonomy. Washington, DC: USDA, 2010.

VELLAME, L. M.; COELHO FILHO, M. A.; COELHO, E. F.; FRAGA JÚNIOR, E. F. Lisímetro de pesagem e de lençol freático de nível constante para uso em ambiente protegido. Revista Caatinga, v. 25, n. 1, p. 153-159, 2012.

WEINTRAUB, P. G.; RECHT, E.; MONDACA, L. L.; DIAZ, B. M.; BENNISON, J. Arthropod pest management in organic vegetable greenhouses. Journal of Integrated Pest Management, v. 8, n. 1, p. 1-14, 2017.

ZHU, J.; PENG, Q.; LIANG, Y.; WU, X.; HAO, W. Leaf gas exchange, chlorophyll fluorescence, and fruit yield in hot pepper (Capsicum anmuum L.) grown under different shade and soil moisture during the fruit growth stage. Journal of Integrative Agriculture, v. 11, n. 6, p. 927-937, 2012. 